\title{
Forebygging av legionærsykdom i sykehus
}

\author{
Sammendrag \\ Bakgrunn. I 2005 ble det for første \\ gang påvist legionellasmitte ved et \\ norsk sykehus. Vi beskriver de mest \\ kjente metoder for sanering av Legio- \\ nella på sykehus.
}

Materiale og metode. Artikkelen er basert på egne erfaringer med tiltak for å forebygge legionærsykdom ved sykehus samt ikke-systematisk søk i PubMed.

Resultater. Det finnes flere metoder for å bekjempe Legionella ved sykehus, som klorering, varmebehandling og bruk av filtre. Etter sanering av Legionella skjer det imidlertid raskt rekontaminering. Tilsetting av sølv- og kobberioner i vann er en godt dokumentert metode for systemisk og langvarig sanering av Legionella i vann. Ulempen med dette tiltaket er høye kostnader, fare for misfarging av vann og mulighet for resistensutvikling hos miljøbakterier. Denne resistensmekanismen kan teoretisk overføres til sykdomsfremkallende bakterier.

Fortolkning. Vi anbefaler tilsetting av sølv- og kobberioner i vann som metode for forebygging av nosokomial legionærsykdom når man mislykkes med standardmetoder og har høy forekomst av Legionella i vann. Misfarging av operasjonsinstrumenter som forekommer ved høye sølvkonsentrasjoner, kan unngås ved egen vannforsyning til operasjonsenheter.

\author{
Marjut Sarjomaa \\ marjut.anneli.sarjomaa@sthf.no \\ Per Urdahl \\ Medisinsk klinikk \\ Sykehuset Telemark \\ Skien \\ Einar Ramsli \\ Bygg og eiendomsseksjon \\ Carl-Fredrik Borchgrevink-Lund \\ Enhet for smittevern \\ Sykehuset Telemark \\ Eirik Ask \\ Avdeling for miljømikrobiologi \\ Unilabs Telelab \\ Skien
}

Smitte via aerosoler i luft er den mest kjente smitteveien for legionærsykdom (1). Ved det første utbruddet av legionærsykdom i 1976 i USA kom smitten sannsynligvis fra et system for luftkjøling på et konferansehotell $(2,3)$. I den senere tid har det vært fokusert mye, ifølge noen forskere for mye, på kjøletårn som smittekilde ved epidemiske utbrudd (4).

I studier fra Storbritannia, USA og Canada gjennomført i perioden 1985-94 fant man Legionella i vann ved $12-70 \%$ av sykehusene $(5,6)$. I 2005 ble det påvist legionellasmitte via aspirasjon ved Sykehuset Telemark. Det var systemisk kontaminasjon av både varmt- og kaldtvannsanlegget til tross for iverksatte standardtiltak. I Trondheim hadde man et enkelt tilfelle av nosokomial legionærsykdom der smittekilden ble identifisert i et varmtvannsanlegg (7). Det er ikke tidligere beskrevet utbrudd av nosokomial legionærsykdom ved norske sykehus.

Store og komplekse vannsystemer på sykehus er ideelle reservoarer for Legionella (8). Det er vanskelig å definere hva som er en akseptabel legionellakonsentrasjon i vann på sykehus som har pasienter med nedsatt immunforsvar. En konsentrasjon på $1000 \mathrm{cfu} / 1 \mathrm{er}$ foreslått som en teoretisk grense for å utvikle sykdom (8). Cfu (Colony forming units) underestimerer det reelle antall levende legionellabakterier i vannet, siden en cfu kan representere flere legionellaceller (9). I stedet for cfu kan man som måleinstrument bruke prosent av distale tappesteder som har legionellavekst (10). Dersom $30 \%$ eller flere av vannprøvene viser legionellavekst, er vannet helt klart kontaminert $(10,11)$.

Det er funnet i flere studier at gjennomsnittlig temperatur i varmtvannstankene på sykehus er $45-50{ }^{\circ} \mathrm{C}$, noe som er ideelt for legionellavekst (5). Ved temperatur over $60{ }^{\circ} \mathrm{C}$ vil legionellabakteriene ikke etablere seg eller vokse (1).

Hensikten med denne artikkelen er å beskrive metoder for å bekjempe Legionella i vann og forebygge utbrudd av nosokomial legionærsykdom ved sykehus (ramme 1).

\section{Materiale og metode}

Artikkelen er basert på et ikke-systematisk søk i PubMed og på forfatternes erfaringer med sanering av Legionella og forebygging av legionærsykdom på sykehus.

\section{Smitteveier på sykehus}

Aerosoldanning, aspirasjon og direkte installasjon av bakterien i lungene ved manipulasjon av respirasjonskanal, er de hyppigste smitteveiene for Legionella på sykehus (12). Dusjing med aerosoldanning er ofte påstått å være en hyppig smittevei for Legionella på sykehus. Overraskende nok viser noen studier at dusjing kan forebygge legionærsykdom (12). Det forklares med at pasienter som dusjer er ofte mindre syke enn sengeliggende pasienter og har derfor mindre aspirasjonsfare. Prospektive studier viser at dusjing ikke er assosiert med nosokomial legionærsykdom (13).

Den viktigste risikofaktoren for nosokomial pneumoni er aspirasjon (4). Fremmedlegemer, som involverer oropharynx, er de viktigste risikofaktorene for mikroaspirasjon $(4,13)$. Ved kronisk obstruktiv lungesykdom (kols) er den beskyttende funksjonen av luftveiene nedsatt, og sykdommen er assosiert med aspirasjon (4). Aspirasjon skjer oftere blant sengeliggende personer når de drikker liggende enn ellers (1). Selv et tappevannanlegg med lav forekomst av Legionella, kan være årsak til sykdom hos

\section{Hovedbudskap}

- Legionella kan forårsake utbrudd av infeksjon på sykehus via aspirasjon fra kontaminert vann

- Varmebehandling og klorering av vann har systemisk, men kortvarig saneringseffekt

- Installasjon av sølv- og kobberionanlegg på sykehus er en godt dokumentert systemisk metode for bekjempelse av Legionella i vann 


Ramme 1
Metoder for legionellabekjempelse
på sykehus
- Klorering og sjokk-klorering
- Varmebehandling
- Bakteriologisk barriere med filter
- Ozon
- Ultrafiolett lys
- Monokloramin
- Tilsetting av sølv- og kobberioner

mennesker med nedsatt immunforsvar (10). Vanndråper på medisinsk utstyr som føres ned i lungene, kan være infisert med Legionella (1).

Siden 1982 har man oppdaget i epidemiologiske studier at den viktigste smitteveien for legionærsykdom på sykehus er smitte via infisert vann (12). Siden 1985 er det bare i én av flere hundre internasjonale rapporter av nosokomial legionærsykdom rapportert kjøletårn som smittekilde (12).

Legionella kan føres ned i luftveier via kontaminerte puritanfuktere. Det anbefales å bruke sterilt vann ved skylling av nasogastriske sonder for å forebygge nosokomial legionærsykdom (13). Sterilt vann bør benyttes i alt medisinsk utstyr der legionellasmitte kan overføres (1).

\section{Metoder for bekjempelse \\ Klorering}

Installasjon av klor i vannsystem er en kjent metode for legionellabekjempelse både i varmt- og kaldvannssystemet (14). Etter sjokk-klorering gjennomføres det en kontinuerlig hyperklorering av vannet. Det er umulig å få fjernet Legionella fullstendig fra vannsystemet, og rekontaminering skjer derfor lett (14). Metoden krever nøye monitorering av klornivået og personell til å utføre arbeidet (14). Klor kan brukes ved utbruddssituasjoner eller for langvarig sanering av Legionella (1). Klor har ingen effekt på Legionella i blindledninger, og over tid har klor korroderende effekt på rør. Legionella danner en biofilm sammen med andre mikrober og amøber i rørsystemet. Bakterier i biofilmen er mer motstandsdyktige mot biocider og varmebehandling enn fritt sirkulerende bakterier (5). Legionella blir bare supprimert ved hyperklorering. Høye klorkonsentrasjoner kan fremkalle danning av karsinogener som trihalometaner (5).

\section{Varmebehandling}

Legionella vokser best ved temperaturer mellom $20^{\circ} \mathrm{C}$ og $50{ }^{\circ} \mathrm{C}$ (1). Sjokkvarmebehandling og skylling var en av de forste metodene som ble etablert for bekjempelse av Legionella. Metoden er billig, har kortvarig
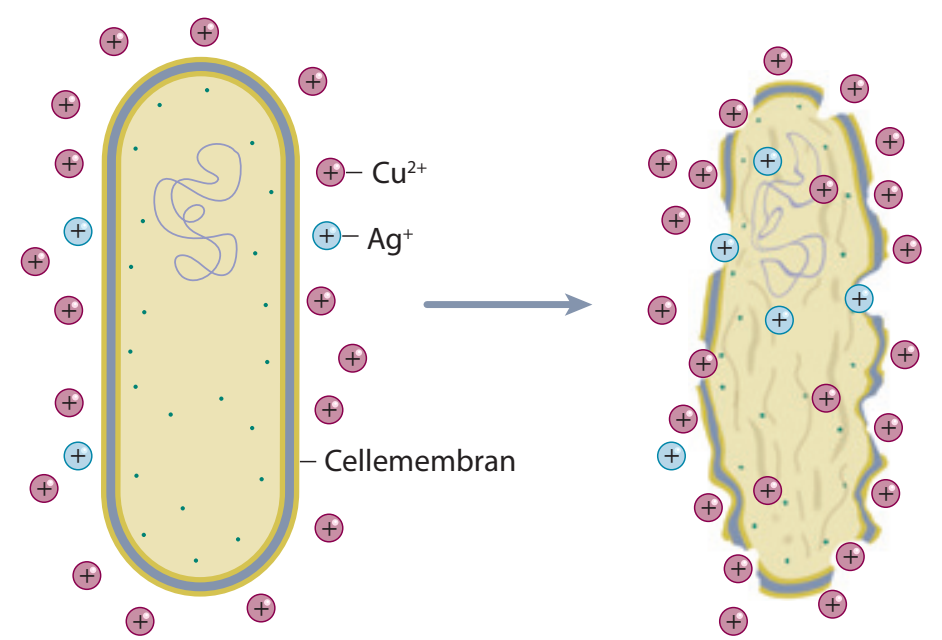

Figur 1 Positivt ladede ioner som sølv (Ag+) og kobber (Cu2+), knyttes mot den negativt ladede celleveggen på organismer. Denne elektrostatiske knyttingen skaper stress som gjør at celleveggen blir brutt ned. Sammen med proteindenatureringen forårsaker dette cellelyse og hindrer celledelingen

systemisk effekt, og er sammen med klor anbefalt metode for forebygging av Legionella i vann og ved utbrudd på sykehus (1). Varmtvannstanktemperaturen økes til $70{ }^{\circ} \mathrm{C}$ i minst fem minutter (1). Fare for skolding er til stede (1). Metoden er tid- og personellkrevende. Det er stor fare for rekolonisering (14). Biofilm danner seg på nytt og gir gode vekstvilkår for bakterier. Sjokkvarmebehandling har liten effekt $i$ et rørsystem der blindledninger er koloniserte (1).

I Finland ble det i 1995 utført sjokkvarmebehandling på et sykehus etter utbrudd av legionærsykdom med Legionella pneumophila serogruppe 5 (15). Sjokkvarmebehandlingsenhet ble installert etter at man ikke lyktes med engangs sjokkvarmebehandling. Man hadde ufullstendig effekt både på fjerning av Legionella i vann og på forekomst av nosokomiale legionærsykdomstilfeller $(8,15)$.

\section{Ozon}

Ozon er et kraftig oksidasjonsmiddel. Det kreves kontinuerlig ozonkonsentrasjon 1-2 $\mathrm{mg} / \mathrm{l}$ i vann for å få tilstrekkelig reduksjon av legionellakonsentrasjonen $(1,14)$. Ozon er internasjonalt kun anbefalt som supplement til varmebehandling eller klor $(1,14)$.

\section{Ultrafiolett lys}

Man oppnår rask lokal bakteriedrepende effekt av ultrafiolett lys (UV-lys) i løpet av 20 minutter (14). Dette er ikke anbefalt som eneste metode på sykehus, fordi Legionella persisterer i biofilm, som er utilgjengelig for UV-lys (5). Anlegget må installeres distalt ved tappested for vann. Det anbefales samtidig bruk av bakteriologiske filtre, noe som også øker kostnadene. UV-lys anbefales ikke i vannanlegg som allerede er kontaminert med Legionella (14).

\section{Monokloramin}

Monokloramin dannes ved at klor og ammonium blandes $i$ vannet $i$ et gitt forhold. Det er begrensede erfaringer med denne metoden (1).

\section{Bakteriologisk barriere med filter}

Installasjon av lokale fysiske barrierer med filtre er en relativt enkel metode ved spesielt utsatte avdelinger. Filtrene er effektive, og man får en absolutt barriere mot Legionella. I tillegg får man en barriere mot andre vannervervede agens som Mycobacterium spesies, Pseudomonas aeruginosa og Acinetobacter spesies. Vannet utsettes ikke for biocider eller kjemikalier. Filtrene har langvarig effekt, men ikke effekt i hele vannanlegget fordi filtrene installeres distalt på tappesteder. For å få effekt $i$ hele vannanlegget krever metoden omfattende personellressurser til å skifte filtrene ukentlig på alle distale tappesteder. Dette kan være vanskelig å gjennomføre i store bygninger som sykehus $(16,17)$.

Tilsetting av sølv- og kobberioner i vann Tilsetting av sølv- og kobberioner i vann (fig 1, fig 2) er en systemisk metode for langvarig bekjempelse av Legionella $(1,5)$. Verdens helseorganisasjon (WHO) har i sine retningslinjer maksimumsgrenser for sølv: $0,1 \mathrm{mg} / \mathrm{l}, \mathrm{og}$ for kobber $2,0 \mathrm{mg} / \mathrm{l}$ i vann (18). Misfarging av tøyvask og sanitærutstyr forekommer ved et kobbernivå høyere enn $1 \mathrm{mg} / \mathrm{l}$. Man kan få en uønsket bitter smak på vannet ved kobbernivå over $2,5 \mathrm{mg} / \mathrm{l}$. Ved enda høyere konsentrasjon kan vannet bli misfarget. Det er en teoretisk mulighet for en resistensutvikling mot sølv og kobber, men det er så langt ikke påvist (5). Høy pHverdi i vannet kan minske effekten av kobberioniseringen (19).

I Finland undersøkte man i 2001 den bakteriedrepende effekten av sølv- og kobberioner mot Legionella og Mycobacterium (20). Man påviste at fritt Legionella i vannet ble totalt destruert. For å oppnå effekt av ioniseringen, er det viktig at vannkraner og dusjer blir regelmessig brukt. Kobber penetrerer biofilm bedre enn sølv. Forfatterne konkluderer med at et godt overvåket ionanlegg kan være løsning for å forhindre nosokomial legionærsykdom (20). 


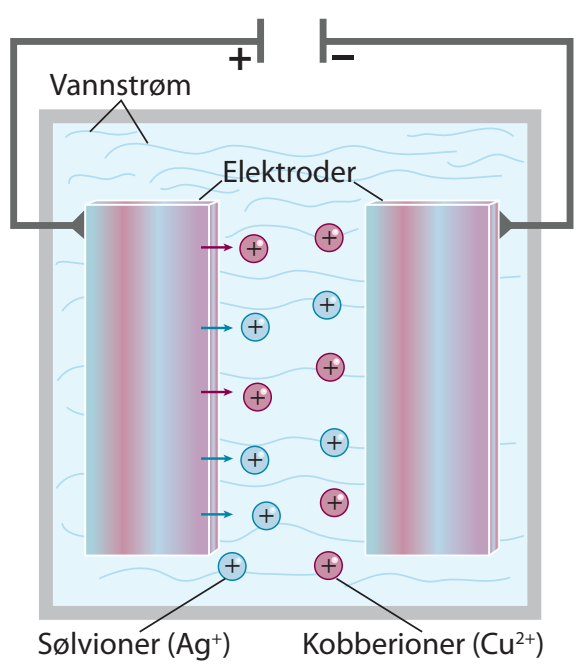

Figur 2 Vedåkjøre likestrøm gjennom sølv-og kobberelektroder som er senket i vann, blir disse positivt ladede ionene frigjort i vannet. Når man kjører vannstrøm mellom elektrodene, vil de metalliske ionene flyte inn i vannanlegget før de når den motsatte elektroden

Enhver ny metode for legionellabekjempelse bør ha gjennomgått en trinnvis standardisert evaluering før den tas i bruk på sykehus. Metoden må ha in vitro-effekt på Legionella, og effekten må vises i kontrollerte studier (21). I en multisenterstudie om effekten av bruk av sølv- og kobberioner ble det ikke rapportert om legionærsykdomstilfeller i studieperioden over fem år, bortsett fra ett enkelt tilfelle på et sykehus rett etter installasjon av metoden (21). Alle sykehusene hadde hatt legionærsykdomstilfeller før installasjonen. Alle hadde også forsøkt standard metoder for å bekjempe Legionella, som sjokk-klorering og sjokkvarmebehandling, uten å lykkes. Sykehusene fikk installert sølv- og kobberioner i perioden 1989-95. Før installasjon av anlegg for ioniseringen, rapporterte $47 \%$ av sykehusene legionellakontaminasjon i mer enn $30 \%$ av vannprøvene. Legionella pneumophila serogruppe 1 ble rapportert i $75 \%$ av tilfellene. Sykehusene hadde ved studieavslutning i 2000 benyttet metoden gjennomsnittlig i sju år. Ved studieoppstart i 1995 rapporterte halvparten av sykehusene at de ikke hadde hatt kontaminasjon av vannet med Legionella etter installasjon av sølv- og kobberionanlegget. Ved kontroll etter fem år fra studieoppstart var det fortsatt $43 \%$ av sykehusene som ikke hadde hatt noen legionellakontaminasjon i vannet. Resten hadde hatt forekomst av Legionella i mindre enn $30 \%$ av vannprøvene. Det ble rapportert om misfarging av vannet ved høye sølvkonsentrasjoner (21).

Det er i Norge generelt ikke tillatt med sølv- og kobbertilsetning til vann på grunn av virkningen det vil ha på rensing av avløpsvann og muligheten til å deponere kloakkslam. Folkehelseinstituttet og Mattilsynet har imidlertid kommet til at det bør være tillatt med en begrenset tilsetning av sølv- og kobberioner i vannet for å forhindre at utsatte grupper mennesker blir rammet av legionærsykdom. Sykehuset i Telemark søkte dispensasjon fra Mattilsynet og fikk innvilget dette i 2008. Siden 23.6. 2009 godkjenner Mattilsynet bruk av kobber- og sølvioner $\mathrm{i}$ interne vannfordelingsnett når den offentlige helsetjenesten mener at mengden Legionella i vann er så høy at det helsemessige problemet kun kan håndteres ved bruk av slike metoder (22).

Sølv absorberes via mage-tarm-kanalen, slimhinner og sår i huden. Mesteparten av det absorberte sølvet utskilles med gallen i feces $(1,18)$. Folkehelseinstituttets vurdering var at den planlagte sølvkonsentrasjonen på 40 $\mu \mathrm{g} / \mathrm{l}$ ikke utgjør noen helserisiko for ansatte og pasienter ved et sykehus $(1,18)$.

Kobber er et viktig spormetall, men forurenser også drikkevann. Kobber absorberes primært i tynntarm, og det meste transporteres til lever, hvor det inngår i proteiner. Kobber skilles ut via feces. Det er dokumentert tilfeller av akutt og kronisk kobberforgiftning. For voksne er langtidsinntak i konsentrasjoner på $1-10 \mathrm{mg} / \mathrm{dag}$ ikke skadelig (18). EU har angitt at maksimumskonsentrasjon av kobber i drikkevann er $2 \mathrm{mg} / \mathrm{l}$, noe som samsvarer med WHOs retningslinjer for drikkevann fra 2002 (18).

Sølv og kobber er tungmetaller, og det er derfor ønskelig å redusere mengden av disse metallene i naturen. Sølv vil i større grad enn kobber akkumuleres i jordsmonnet. Omfattende bruk av sølv, som tilføres avløpsvannet, kan være en medvirkende årsak til utvikling av antibiotikaresistens hos miljøbakterier (5). Denne resistensmekanismen kan teoretisk overføres til sykdomsfremkallende bakterier.

\section{Erfaringer fra Sykehuset Telemark}

Flere mislykkede forsøk med varmebehandling og klorering for å fjerne Legionella i varmt- og kaldtvannsrørene var årsaken til at man ville finne en permanent metode for sanering av Legionella ved Sykehuset Telemark. Vi ønsket å behandle systemisk alt tappevann fordi Legionella ble påvist $i$ hele vannanlegget. Det hadde blitt for omfattende arbeid å bruke filtre på alle distale tappesteder. Det ble installert anlegg med sølv- og kobberioner i mars 2008. Anlegget hadde en innkjøpspris på 750000 kroner og generer årlige driftskostnader på rundt 75000 kroner. Ledningsanlegget består av kobberrør og har derfor høyt kobberinnhold. Det tas månedlige cfu-målinger og sølv- og kobberionkonsentrasjonsmålinger i vannet fra ulike steder. Det er ikke funnet sykdomsfremkallende legionellastammer ved prøvetaking. De første månedene etter installasjonen ble det rapportert om bitter smak på vannet og misfarging av sanitærutstyr. Det oppsto problemer med misfarging av operasjonsinstrumenter. Sykehuset har fortsatt, men i mindre grad, problemer med misfarging av operasjonsinstrumenter. Vannet er fortsatt ikke fritt for Legionella, men det er ikke påvist sykdomsfremkallende legionellastammer etter installasjon av renseanlegget.

\section{Konklusjon}

Sykehusene i Norge må regne med forekomst av Legionella i vann og nosokomiale legionærsykdomstilfeller. Vannet som sykdomsfremkallende smittekilde er en kontinuerlig trussel som sykehusene må være godt forberedt på. Tilsetting av sølv- og kobberioner i vann er en godt dokumentert metode for systemisk og langvarig sanering av Legionella i vann. Anlegget har høy pris, resistensutvikling for miljøbakterier er mulig, og misfarging av instrumenter på sykehus kan forekomme ved høye kobbernivåer.

\section{Marjut Sarjomaa (f. 1967)}

er spesialist i indremedisin og er overlege på Infeksjonsavdelingen, Sykehuset Telemark.

Nåværende stilling er lege i spesialisering for infeksjonssykdommer ved Sykehuset i Vestfold. Ingen oppgitte interessekonflikter.

\section{Per Urdahl (f. 1953)}

er spesialist $\mathrm{i}$ indremedisin og klinikksjef for Medisinsk klinikk, Sykehuset Telemark. Ingen oppgitte interessekonflikter.

\section{Einar Ramsli (f. 1955)}

er dr.ing. med automatisering/robotteknikk. Han har ti års forskererfaring og er nå eiendomssjef ved Sykehuset Telemark.

Ingen oppgitte interessekonflikter.

\section{Carl-Fredrik Borchgrevink-Lund (f. 1949)}

er utdannet operasjonssykepleier og hygienesykepleier. Arbeider som hygienesykepleier ved Sykehuset Telemark.

Ingen oppgitte interessekonflikter.

\section{Eirik Ask (f. 1961)}

er cand.scient. og seniorrådgiver ved Avdeling for mikrobiologi, Unilabs Telelab.

Ingen oppgitte interessekonflikter.

\section{Litteratur}

1. Folkehelseinstituttet. Forebygging av legionellasmitte - en veiledning. www.fhi.no/eway/ default.aspx?pid=233\&trg=MainLeft_5631\& MainArea_5661 $=5631: 0: 15,4729: 1: 0: 0: \cdots: 0: 0 \&$ MainLeft_5631=5544:80826::1:5590:2:::0:0 (26.5.2011).

2. Fraser DW, Tsai TR, Orenstein W et al. Legionnaires' disease: description of an epidemic of pneumonia. N Engl J Med 1977; 297: 1189-97.

3. McDade JE, Shepard CC, Fraser DW et al. Legionnaires' disease: isolation of a bacterium and demonstration of its role in other respiratory disease. N Engl J Med 1977; 297: 1197-203.

4. Yu VL. Cooling towers and legionellosis: a conundrum with proposed solutions. Int J Hyg Environ Health 2008; 211: 229-34

5. Lin YS, Stout JE, Yu VL et al. Disinfection of water distribution systems for Legionella. Semin Respir Infect 1998; 13: 147-59.

6. Nazarian EJ, Bopp DJ, Saylors A et al. Design and implementation of a protocol for the detection of Legionella in clinical and environmental samples. Diagn Microbiol Infect Dis 2008; 62: 125-32. 
7. Garåsen H, Sagvik E, Kvendbø JF et al. Legionella i Trondheim -smitteoppsporing og miljøkartlegging. Tidsskr Nor Legeforen 2005; 125: 1791-3.

8. Kusnetsov J, Torvinen E, Perola $\mathrm{O}$ et al. Colonization of hospital water systems by legionellae, mycobacteria and other heterotrophic bacteria potentially hazardous to risk group patients. APMIS 2003; 111: 546-56.

9. Perola O, Kauppinen J, Kusnetsov J et al. Persistent Legionella pneumophila colonization of a hospital water supply: efficacy of control methods and a molecular epidemiological analysis. APMIS 2005; 113: 45-53.

10. Exner M, Kramer A, Lajoie L et al. Prevention and control of health care-associated waterborne infections in health care facilities. Am J Infect Control 2005; 33(suppl 1): S26-40.

11. Best M, Yu VL, Stout J et al. Legionellaceae in the hospital water-supply. Epidemiological link with disease and evaluation of a method for control of nosocomial legionnaires' disease and Pittsburgh pneumonia. Lancet 1983; 322: 307-10.

12. Sabria M, Yu VL. Hospital-acquired legionellosis: solutions for a preventable infection. Lancet Infect Dis 2002; 2: 368-73.

13. Stout JE, Yu VL. Nosocomial Legionella infection. I: Mayhall CG, red. Hospital epidemiology and infection control. 2. utg. Philadelphia, PA: Lippincott Williams \& Wilkins, 1999: 456-7.

14. Muraca P, Stout JE, Yu VL. Comparative assessment of chlorine, heat, ozone, and UV light for killing Legionella pneumophila within a model plumbing system. Appl Environ Microbiol 1987; 53: bing systen

15. Perola O, Kauppinen J, Kusnetsov J et al. Nosocomial Legionella pneumophila serogroup 5 outbreak associated with persistent colonization of a hospital water system. APMIS 2002; 110: 863-8.

16. Sheffer PJ, Stout JE, Wagener MM et al. Efficacy of new point-of -use water filter for preventing exposure to Legionella and waterborne bacteria. Am J Infect Control 2005; 33 (suppl): S20-5.

17. Ortolano GA, McAlister MB, Angelbeck JA et al. Hospital water point-of-use filtration: a complementary strategy to reduce the risk of nosocomial infection. Am J Infect Control 2005; 33: 1-18.

18. WHO Guidelines for Drinking-water quality. Genève: WHO, 2004.

19. Lin YS, Vidic RD, Stout JE et al. Negative effect of high $\mathrm{pH}$ on biocidal efficacy of copper and silver ions in controlling Legionella pneumophila. Appl Environ Microbiol 2002; 68: 2711-5.

20. Kusnetsov J, livanainen E, Elomaa N et al. Copper and silver ions more effective against legionellae than against mycobacteria in a hospital warm water system. Water Res 2001; 35: 4217-25.

21. Stout JE, Yu VL. Experiences of the first 16 hospitals using copper-silver ionization for Legionella control: implications for the evaluation of other disinfection modalities. Infect Control Hosp Epidemiol 2003; 24: 563-8.

22. Hofshagen T. Sølv og kobber til Legionellabekjemping. Norsk Vann 23.6.2009. http://norskvann.no/ (26.5.2011).

Mottatt 13.8. 2009, første revisjon innsendt 27.10. 2009, godkjent 26.5. 2011. Medisinsk redaktør

Trine B. Haugen. 